\title{
The Effectiveness of Rational Emotive Behaviour Therapy Approach Counselling on Students' Prosocial Behaviour
}

\author{
Wisnu Kurniawan ${ }^{1 *}$, Sigit Sanyata ${ }^{2}$ (D) \\ ${ }^{1,2}$ Postgraduate Guidance and Counseling Study Program, Yogyakarta State University, Indonesia \\ *Corresponding author: wisnukurniawan.2017@student.uny.ac.id
}

\begin{abstract}
Prosocial behaviour needs to be developed because it is needed to make it easier to interact and establish relationships with others. This study aims to determine the level of effectiveness of group counselling in the Rational Emotive Behaviour (REBT) approach to the improvement of prosocial behaviour in class XI students. This type of research is quantitative with a form of quasi-experimental research. The subjects of the study were 132 students. The instrument used was a scale that contained 51 statement items. Analysis of the data used in this study is the Wilcoxon Signed Rank Test using the help of IBM SPSS v.22. The Wilcoxon Signed Rank Test is used to test the differences and the magnitude of the pre-test and posttest results. This research went through four steps pre-test and post-test to get the results that were wanted. The results of the fourth per-test and post-test revealed that if $(p)=0.018$, it was smaller than $0.05(0.018<0.05)$, which means it had a high level of effectiveness, meaning that there were differences in prosocial behaviour before and after group counselling using the Rational Emotive Behaviour (REBT) approach.
\end{abstract}

Keywords: Group Counselling, REBT, Prosocial Behaviour

\begin{tabular}{|c|c|c|}
\hline History: & & Publisher: Unc \\
\hline Received & : March 18, 2021 & Licensed: This \\
\hline Revised & : March 20, 2021 & a Creative Com \\
\hline Accepted & : April 29, 2021 & (c) (†) () \\
\hline Published & : July 25, 2021 & $0 \mathrm{EY}_{\mathrm{SA}}$ \\
\hline
\end{tabular}

\section{INTRODUCTION}

Grade XI students are students who occupy the bench High School (SMA), based on the development phase, these students are included in the category of adolescents entering the phase in conditions of the transition to adult puberty. Someone can be said to have entered the adolescent phase is a transition from the phase of children, but he is still not mature enough to be said to be an adult individual, so in this adolescent phase began to look for identity (Schumm \& Bogner, 2016; Sumara et al., 2017). In adolescence, many problems arise in individuals and from their environment (Borup et al., 2014; Putri et al., 2019). Adolescents who are in their growth and development period will continue to have social relationships both in the form of groups and individuals (Afa et al., 2020; Putri et al., 2019). Talking about the social aspects, at the age of entering class XI students begin to get to know and experience socialization with fellow humans more intensely than in the previous phase. Adolescence is a transition period from children to adults (Yulianingsih et al., 2020). It is further explained that currently there are changes in child development, both physical, cognitive, and psychosocial development that require adaptation in children

Continuing the presentation on social aspects, there is one social aspect called prosocial that is experienced by students. Prosocial behavior as behavior that is done voluntarily, benefits others without anticipating external rewards, and the behavior is carried out not for himself, including helping/aiding, sharing, and donating (Desmita, 2011; Martela \& Ryan, 2016). All of these actions have positive consequences. The forms of prosocial behavior are contrary to the behavior of aggression, anti, destructive, selfish, crime, and others. Prosocial behavior is the ability of individual behavior to voluntarily or plan to help others, both materially and psychologically to change things for the better, regardless of the helper's motive, and provide benefits to the recipient of assistance (Heriyani \& Dewi, 2017). 
If prosocial behavior is behavior that provides benefits to others by helping to relieve physical or psychological burdens, which is done voluntarily (Bashori, 2017). It can take many forms, maybe even risky if the person helps him

In the development of the social aspect called prosocial, the role of the guidance and counseling teacher in the school is very large because most of the student's time is spent in school and social interaction in (Heriyani \& Dewi, 2017) school environment, the need for the role of the counseling guidance teacher so that there are no social deviations that will be committed by students. According to some previous research results, the Rational-Emotive Behavior Therapy (REBT) approach is a cognitive-behavioral approach that emphasizes the interrelationship between feelings, behavior and, thoughts. The rational emotive behavior therapy approach is a cognitive-behavioral approach that emphasizes indicators of feelings, behavior, and thoughts (Novilda et al., 2019; Pebriyanti, 2020). REBT is an approach in counseling that helps clients change the client's irrational views and beliefs to become rational, helps change attitudes, ways of thinking, and perceptions, therefore clients are expected to be able to develop and develop. achieve optimal self-realization (Hapsyah et al., 2019). REBT is a cognitive-behavioral counseling approach that aims to understand and overcome negative emotional and behavioral problems that stem from irrational beliefs (Misdeni et al., 2019; Novilda et al., 2019). Apart from that, another advantage of the Rational Emotive Behavior Therapy (REBT) approach is that it is clear, easy to learn, and effective. The Rational Emotive Behavior Therapy (REBT) approach can be easily combined with other behavioral techniques to help clients experience more of what they are learning (Milatillah, 2019).

Talking about the prosocial behavior of students in the community lately experienced an indication of decreased social awareness and sensitivity to other people occurs in adolescents who appear to be more selfish and successful without considering the circumstances of others around them. In line with this opinion, several studies revealed similar research explain that if there is a phenomenon in Denpasar City related to a decrease in prosocial behavior, there are cases that show low prosocial behavior among adolescents in Denpasar City (Maha et al., 2018). The lack of willingness of students to behave prosocial in the community was caused by several factors, one of the factors which were very influential in the support of parents (Elistantia et al., 2018). Furthermore, it was revealed that students' prosocial behavior decreased with age, so they needed both internal and external support to be able to improve the behavior.

Based on the explanation above about the Rational-Emotive Behavior Therapy (REBT) counseling approach and issues regarding the decline and lack of prosocial attitudes of students lately, the researcher wants to research whether the Rational-Emotive Behavior Therapy (REBT) approach through group counseling can improve students' prosocial behavior. The purpose of this study was to measure the effectiveness of the Rational-Emotive Behavior Therapy (REBT) approach through group counseling to improve the prosocial behavior of class XI students. This research was conducted because there is still a lack of research that links these variables, especially in class XI students, even though some literature studies mention that prosocial behavior is the basic behavior of human nature which is a social creature. Therefore, researchers pay attention to the need for renewal of research results regarding the effectiveness of the Rational-Emotive Behavior Therapy (REBT) approach through group counseling on the prosocial behavior of class XI students.

\section{MATERIALS AND METHODS}

This type of research is quantitative in the form of quasi-experimental research using design times series which means that this design uses only one group without a comparison 
group or a control group (Sugiyono, 2019). Condition, the group was given a pre-test four times, to know the stability and clarity of the group's condition before being treated. The design of this design in the study, the pre-test was carried out 4 times, the researcher continued with the intervention for 8 meetings or 1 month. After intervention with REBT approach group counseling, the post-test was carried out 4 times. The population in this study amounted to 132 students of SMK Negeri 4 Madiun City but the subjects used were 7 students of SMK Negeri Madiun because they were per group counseling procedures. The sample selection uses a purposive technique which refers to the data analysis notes from the school counselor and the researchers' criteria where the researcher adjusts to students who have problems related to low prosocial behavior. Before the scale is spread to be filled out by students, the validity and reliability tests are first performed with the results of 51 valid items (72.86\%) and 19 invalids/improper items (27.14\%). Cronbach's alpha value of reliability test results from 0.948. Data in this study were calculated using non-parametric statistics. Hypothesis testing is to determine the significance of the difference between pre-test and post-test, then the data are analyzed using the Wilcoxon Signed Rank Test. The Wilcoxon Signed Rank Test is calculated using the help of IBM SPSS v.22. The Wilcoxon Signed Rank Test is used to test the differences and the magnitude of the pre-test and post-test results.

\section{RESULTS AND DISCUSSION}

\section{Results}

Based on the research that has been done, the research data is obtained, namely in 4 times the pretest and post-test results in the first pre-test and post-test showing that there is no difference between the first pre-test and post-test. Based on the data analysis, it can be seen that the results obtained after the calculation are shown from the value $(\mathrm{p})=0.612$ greater than 0.05 (0.612 \& gt; 0.05), so at the initial meeting and the first test, it shows that there is no difference between pre- first or first test and post-test. Then because the results obtained were not following the wishes in the study, the second meeting was carried out again in the counseling and test sessions carried out, to test the hypothesis in the pre-test and post-test the second result showed that there was no difference between the second pre-test and post-test.

Based on the analysis data, it can be seen that the results obtained after the calculation are shown from the value $(\mathrm{p})=0.128$ greater than $0.05(0.128>0.05)$, then the second difference test at the third and fourth meeting of the counseling session and the second test shows there is no difference between the second pre-test and post-test. Because the second meeting also did not meet the criteria and desires expressed in the study, the next meeting was conducted again at the counseling and test sessions conducted, to test the hypothesis in the third pre-test and post-test showed that there was a difference between the pre-test and post-test.

Based on the data analysis, it can be seen that the results obtained after the calculation are shown from the value $(\mathrm{p})=0.028$ less than $0.05(0.028<0.05)$, then in the third difference test at the fifth and sixth meeting of the counseling session and the third test shows that there is already a difference between the third pre-test and post-test after the third test was carried out which found the difference, then the researcher conducted the fourth session to test the hypothesis in the fourth or last pre-test and post-test. The result of analysis data shows that there is a significant difference between the pre-test and post-test. It is shown from the value $(\mathrm{p})=0.018$ smaller than $0.05(0.018<0.05)$, and the absence of negative values in the Wilcoxon test data description which was carried out on 7 students as research subjects, then in the fourth difference test at the seventh meeting and the eight counseling sessions and the fourth test showed that there was a significant difference between the fourth pre-test and post-test. Then to make it easier to read the results of the research based on the first to fourth 
meeting sessions, the researcher summarizes them into one table which can be seen in Table 1 .

Table 1. Recapitulation Table of Hypothesis Test Results

\begin{tabular}{cccl}
\hline No & Different Test & P-Value/Nilai $(\mathbf{p})$ & \multicolumn{1}{c}{ Info } \\
\hline 1 & Pre-test - Post-test 1 & 0,612 & Not Significant \\
2 & Pre-test - Post-test 2 & 0,128 & Not Significant \\
3 & Pre-test - Post-test 3 & 0,028 & Significant \\
4 & Pre-test - Post-test 4 & 0,018 & Significant \\
\hline
\end{tabular}

Based on Table 1, the overall results of different tests using the Wilcoxon Matchedpairs signed ranks test show that, at the initial meeting and test in the research, the results of different tests have not shown significant results or there has been no difference, in the second difference test or the third and fourth meeting in The counseling session also has not shown significant results or there has been no difference, whereas in the third difference test or at the fifth and sixth meeting the group counseling session has begun to show differences and in the last difference test and the last counseling session and determining the results of the hypothesis, it shows that there is a significant difference between pre-test and post-test. Based on the results of different tests that have been carried out, it can be concluded that rejecting Ho and accepting Ha means that group counseling with a rational emotive behavior therapy approach is effective on prosocial behavior of class XI students of SMK Negeri 4 Madiun City.

Also, in the implementation of experiments with Rational Emotive Behavior Therapy (REBT) counseling, students are only given information, but they will be given an understanding that humans who were influential in the past have contributed to the formation of life in the present so that it allows students to be more able to interact with the environment social so that it can foster students' prosocial behavior. This activity, it is focused on helping the counselee not only to feel better but by changing his thoughts and behavior, for the better, so that the application of the Rational Emotive Behavior Therapy (REBT) Counseling experiment can be more effective. Through the use of rational emotive behavior therapy (REBT) counseling, students become aware and can think more realistically to change themselves for the better. Those who previously cared less had low empathy and closed themselves off, after receiving rational emotive behavior therapy (REBT) counseling, they became aware and able to behave more prosocial, so that students turn into students who are more caring and increase their prosocial behavior.

\section{Discussion}

The results of the analysis revealed that REBT carried out in group counseling was able to reduce or have a high level of effectiveness in reducing students' prosociality. REBT is considered the best applied in solving this problem because in theory and its application, rational emotional behavior therapy (REBT) counseling has the concept of changing irrational beliefs into new, more rational beliefs so that students are able to think better before doing things that will plunge them into attitudes prosocial negative. The results obtained regarding REBT were able to reduce prosocial weakness in students having concerns with several literature studies that revealed similar results as the results of research on REBT were able to reduce prosocial problems that exist in students. Literature review or theory that reveals the same thing as the research results, Emotional Behavior Rational Counseling in this study is a counseling approach that focuses on emotions, behavior, and thought patterns. Furthermore, explain that this approach is expected to make counselees who were previously considered irrational become rational with the understanding that humans have two 
potentials, namely good (rational) and bad (irrational). Many people emotions without thinking first, so that sometimes cause problems. That is because human feelings arise because of perceptions of specific situations. Under expert opinion related to rational emotive behavior therapy (REBT) counseling that was coined by Albert Ellis which has the basic purpose of changing irrational thoughts into new and more rational thoughts.

It is expected that rational emotive behavior therapy counseling is appropriate for problems in adolescents. REBT approach focuses on individual behavior, but REBT emphasizes that problematic behavior is caused by irrational thinking, in this case, irrational beliefs are shown in students' prosocial behavior so that this approach deals with problems experienced by students (Putri et al., 2019; Voltan Acar \& Şahin, 2019). Furthermore, REBT is a counseling approach that can be placed in the cognitive-behavioral psychotherapy tradition, meaning that it is focused on our way of thinking and behaving, to understand. emotional response (Khaira et al., 2017; Pebriyanti, 2020). This research proves that social problems caused by irrational thinking can be overcome with the REBT approach. As explained in previous research, it explains that a counseling approach that focuses on cognitive in the form of beliefs, assumptions, attitudes, and behaviors in the form of deviant behaviors, is maximal and effective to improve prosocial behavior (Herfidawati, 2018). This is following the character of adolescents who are still unstable and difficult to manage their emotions and tend to act irrationally which can cause problems.

This reason is considered under the concept of the rational emotive behavior therapy (REBT) approach, which demands to think, emotionally, and act following prevailing norms and rules and have rational thoughts. REBT is based on the premise that thoughts, emotions, and behavior affect a person to a large extent and that their behavior, thoughts, and emotions have a reciprocal cause and effect relationship (Voltan Acar \& Şahin, 2019). Besides, research further emphasizes that rational emotive behavior therapy (REBT) counseling can affect the level of student social behavior in society, this is evidenced by the results of research which show that REBT can reduce or decrease withdrawal behavior so that students can increase caring, empathy and prosocial behavior with friends in the surrounding environment (Janah \& Setiawati, 2018). Based on student problems related to low prosocial behavior in vocational high school students who are adolescent phases, it is hoped that this can be assisted by the rational emotive behavior therapy (REBT) approach because according to the explanation above it shows suitability for school students or the teenage phase.

Evidenced by the results of different tests using the Wilcoxon Matched-pairs signed ranks test which showed that at the beginning of the treatment and the tests carried out, it did not show significant differences or changes, but in the third and fourth tests and treatments using rational emotive behavior therapy (REBT) shows significant results. Under the results of research stated that is with the guidance of the rational emotive behavior therapy (REBT) group approach can improve social relations in students (Afa et al., 2020). These results prove that Rational Emotive Behavior Therapy (REBT) counseling is proven to be able to handle social problems, both behaviors and social relations that are very closely related because social relations will also have an impact on student behavior, otherwise increased social behavior will certainly also have an impact on good social relations. Also, the study further emphasized that rational emotive behavior therapy (REBT) counseling can influence the level of social behavior of students in the community (Janah \& Setiawati, 2018).

Research with the title Application of the REBT Approach to Reduce the Level of Withdrawal in High School Students 1 Gedeg shows the results that REBT can reduce or decrease withdrawal behavior (withdrawal) so that students can increase awareness, empathy, and prosocial behavior with friends in the surrounding environment. If the Rational Emotive Behavior Therapy (REBT) group counseling with tafakkur values is effective for increasing the emotional intelligence of young men at the Darul Ihsan Muhammadiyah Prambanan 
(Hadi, 2020). Orphanage, there will be an increase in the results of the emotional intelligence scale also explains that the Rational Emotive Behavior Therapy approach is a structured active-directive therapy that focuses on helping the counselee not only to feel better but by changing his thoughts and behavior, for the better. Deviations in prosocial behavior can be reduced to adverse group counseling (Sari \& Lianawati, 2020).

Group guidance using REBT can increase or have high effectiveness on the nature of student empathy (Latifah, 2019). It was further explained that this approach was also considered capable of fostering and building bad social behavior of students so that they could forge better relationships with their surrounding environment. There was a relationship of fellow welfare with an individual's psychosocial closeness (Martela \& Ryan, 2016). REBT regulatory group was effective in increasing the social adjustment of foster children in the Wira Lisna orphanage (Khaira et al., 2017). Meanwhile, specifically, there is a difference in the average score between the social adjustment of foster children before and after making REBT arrangements. There was an increase in social relations between students through group guidance services with the REBT approach. This is evidenced by the results of the study that students who were given treatment or treatment experienced an average increase in their social relationships (Afa et al., 2020).

There are differences in prosocial behavior between men and women (Van der Graaff et al., 2018). For boys, the stability of prosocial behavior is only up to the age of 14 years and has a peak age of 17 years, but after that, it has decreased prosocial behavior. Furthermore, women do not experience a decline starting from the age of 16 years. social behavior of both men and women at that age including empathic attention is consistently related to subsequent prosocial behavior. The results reveal if one is to foster prosocial behavior by emphasizing measuring moral emotions rather than moral cognition during adolescence. REBT model is able to reduce anger in schizophrenia sufferers and sufferers are able to control anger (Wardani \& Sari, 2018). The REBT approach is effective in changing students' anxiety scores facing exams (Misdeni et al., 2019). The group counseling model with REBT techniques to overcome bullying behavior after being tested by experts can be used for field testing (Purwaningrum \& Pamungkas, 2018).

The use of group counseling is also a determining factor for the effectiveness of the counseling carried out. A comfortable, calm, and conducive place also contribute to the success of counseling. Through group activities, each individual can develop a tolerant attitude, communication skills, ego control which in the end each individual can contribute either directly or indirectly to problem solving (Hidayanti \& Ridhowati, 2019). Group counseling is an effort to help with group situations that are preventive and develop personal abilities as problem-solving in groups or collectively from a counselor to the counselee (Hasnida, 2016). Also, group counseling students can be very useful because through interaction with group members, they will develop various skills which in essence increase trust in others (Muiz \& Miharja, 2017). Social cognitive counseling with role-playing techniques which are effective to increase self-affiliation of class X UPW A students of SMK N 1 Singaraja (Widyanti et al., 2019). Family counseling using the Rational Emotive Behavior Therapy (REBT) approach is a strategy used in realizing family harmony (Putri et al., 2019).

Good concepts and very effective in improving the forms of cognitive and psychosocial behavior in individuals, in this article comparing RBT techniques with REBT and CBT, further explained if the REBT technique is a technique that has a high significance value in improving social and cognitive behavior of individuals (Wirga et al., 2020). REBT counseling can reduce student bullying behavior, it can increase students' awareness and concern for the environment and social behavior in society (Karnelli \& Erismon, 2021). The comfort of the place and environment, the warmth of the atmosphere in the counseling 
process will certainly add to the success in the counseling process. These factors are also considered in the group counseling process of rational emotive behavior therapy (REBT) approaches that have been implemented on students' prosocial behavior problems. Based on the theory that has been applied in the counseling process, it is proven that group counseling approaches rational emotive behavior therapy is effective in improving the prosocial behavior of class XI students of SMK Negeri 4 Madiun City.

\section{CONCLUSION}

Based on the results, discussion, and supported by relevant research, it can be concluded that REBT counseling is quite effective in overcoming problems related to low prosocial behavior caused by irrational beliefs. This can be seen from the changes shown by students before and after the triatomine is carried out, thus strengthening that the REBT treatment is quite effective for low prosocial behavior problems caused by students' irrational beliefs. The results of this study are expected to be a reference in providing REBT counseling in solving students' unfavourable prosocial behavior problems. Despite getting good results through REBT counseling, this study has limitations, namely that the sample only comes from one school. It is hoped that future studies will include a larger sample.

\section{REFERENCES}

Afa, N. M., Abdi, S., \& Batubara, S. (2020). Efektifitas Layanan Bimbingan Kelompok Dengan Pendekatan Rational Emotive Behavior Therapy (Rebt) Untuk Meningkatkan Hubungan Sosial. Guidance Jurnal Bimbingan Dan Konseling Volume, 16(02), 2228. https://doi.org/10.34005/guidance.v16i02.727.

Bashori, K. (2017). Menyemai Perilaku Prososial di Sekolah. Sukma: Jurnal Pendidikan, 1(1), 57-92. https://doi.org/10.32533/01103.2017.

Borup, J., West, R. E., Graham, C. R., \& Davies, R. S. (2014). The adolescent community of engagement: A framework for research on adolescent online ;earning. Journal of Technology and Teacher Education, 22(1), 107-129. https://www.learntechlib.org/primary/p/112371/.

Desmita. (2011). Psikologi Perkembangan Peserta Didik. Remaja Rosda Karya.

Elistantia, R., Yusmansyah, Y., \& Utaminingsih, D. (2018). Hubungan Dukungan Sosial Orang Tua Dengan Perilaku Prososial. ALIBKIN (Jurnal Bimbingan Konseling), 6(1). http://jurnal.fkip.unila.ac.id/index.php/ALIB/article/view/14867.

Hadi, S. (2020). Konseling Kelompok Rational Emotive Behavior Therapy (Rebt) Dengan Nilai Tafakkur Untuk Meningkatkan Kecerdasan Emosional. Urnal Bimbingan Dan Konseling Islam, 10(May), 155-165. http://dx.doi.org/10.29080\%2Fjbki.v10i2.151.

Hapsyah, D. R., Handayani, R., Marjo, H. K., \& Hanim, W. (2019). Bimbingan Kelompok Dengan Pendekatan Rational Emotive Behavior Theraphy (Rebt) Dalam Meningkatkan Motivasi Belajar. Jurnal Selaras : Kajian Bimbingan Dan Konseling Serta Psikologi Pendidikan, 2(1), 23-33. https://doi.org/10.33541/sel.v2i1.1002.

Hasnida, N. L. . (2016). Konseling Kelompok. Edisi Pertama. Kencana Prenada Media Group.

Herfidawati, I. (2018, August). Implementasi pendekatan Cognitive Behavior Therapy terhadap peningkatan perilaku prososial sebagai nilai budaya masyarakat Pemalang. In Prosiding Seminar Nasional Bimbingan dan Konseling (Vol. 2, No. 1, pp. 338345). http://prosiding.unipma.ac.id/index.php/SNBK/article/view/507.

Heriyani, E., \& Dewi, C. (2017). Model Pengembangan Teknik Pembelajaran Life Skill Dengan Setting Group Untuk Meningkatkan Perilaku Prososial Mahasiswa 
Bimbingan Konseling Fkip Universitas Muhamadiyah Prof.Dr. Hamka. Jurnal Psikologi Konseling, 11(2), 1-13. https://jurnal.unimed.ac.id/2012/index.php/Konseling/article/view/13388.

Hidayanti, W. N., \& Ridhowati, D. (2019). Penggunaan Konseling Kelompok Rational Emotive Behavior Therapy (Rebt) Untuk Mengurangi School Refusal (Penolakan Sekolah) Siswa Kelas Xii Ipa Sman 1 Tongas. Vurnal HELPER, 3(5823), 27-36. https://doi.org/10.1136/bmj.3.5823.419-a.

Janah, F. M. (2018). Penerapan Pendekatan Rebt Untuk Menurunkan Tingkat Penarikan Diri (Withdrawal) Pada Siswa SMA Negeri 1 Gedeg. Jurnal BK UNESA, 8(1). https://jurnalmahasiswa.unesa.ac.id/index.php/jurnal-bk-unesa/article/view/22323.

Karnelli, Y., \& Erismon. (2021). Efektivitas pendekatan rational emotive behavior therapy untuk mengatasi perilaku bullying siswa. Educatio, 7(1), 1-13. http://dx.doi.org/10.29210/120212694.

Khaira, I., Firman, F., \& S, N. (2017). Efektivitas Pendekatan Rational Emotive Behavior Therapy (Rebt) Dalam Meningkatkan Penyesuaian Sosial Anak Asuh Di Panti Asuhan Wira Lisna Padang. Bikotetik (Bimbingan Dan Konseling: Teori Dan Praktik), 1(1), 1. https://doi.org/10.26740/bikotetik.v1n1.p1-7.

Latifah, L. (2019). Keefektifan Teknik Drama Segitiga Karpman untuk Meningkatkan Keterampilan Empati Siswa Sekolah Menengah Pertama. Jurnal Kajian Bimbingan Dan Konseling, 4(1), 30. https://doi.org/10.17977/um001v4i12019p030.

Maha, P., Sarasdewi, P., \& Widiasavitri, N. (2018). Hubungan internal locus of control dan kecerdasan emosional terhadap perilaku prososial remaja di Kota Denpasar. Psikologi, Universitas Udayana, 196-206. https://ojs.unud.ac.id/index.php/psikologi/article/download/57841/33789.

Martela, F., \& Ryan, R. M. (2016). Prosocial behavior increases well-being and vitality even without contact with the beneficiary: Causal and behavioral evidence. Motivation and Emotion, 40(3), 351-357. https://doi.org/10.1007/s11031-016-9552-z.

Milatillah, H. (2019). Rasional Emotive Behavior Therapy (Rebt) Untuk Mereduksi Kecanduan Game Online Pada Peserta Didik Smp. Quanta, 3(1), 7-11. https://doi.org/10.22460/q.v1i1p1-10.497.

Misdeni, M., Syahniar, S., \& Marjohan, M. (2019). The Effectiveness of Rational Emotive Behavior Therapy Approach Using a Group Setting to Overcome Anxiety of Students Facing Examinations. International Journal of Research in Counseling and Education, 3(2), 82. https://doi.org/10.24036/0064za0002.

Muiz, G. A., \& Miharja, S. (2017). Peran Layanan Konseling Kelompok Terhadap Perilaku Agresif Pelajar. Irsyad: Jurnal Bimbingan, Penyuluhan, Konseling, Dan Psikoterapi Islam, 5(2), 203-220. http://jurnal.fdk.uinsgd.ac.id/index.php/irsyad/article/view/854.

Novilda, R., Karneli, Y., \& Syukur, Y. (2019). Effectiveness of Rational Emotive Behavior Therapy ( REBT ) Group Format Therapy to Improve Student Self Concepts . International Journal of Applied Counseling and Social Sciences Volume, 01(01), 7987. https://doi.org/10.24036/005316ijaccs.

Pebriyanti, S. (2020). Implementasi Rational Emotive Behavior Therapy pada Orangtua dalam Mendampingi Anak Belajar Masa Covid-19. Golden Age: Jurnal Ilmiah Tumbuh Kembang Anak Usia Dini, 5(2), 63-70. https://doi.org/10.14421/jga.2020.5203.

Purwaningrum, S., \& Pamungkas, B. (2018). Pengembangan Model Konseling Kelompok Dengan Pendekatan Rational Emotive Behavior Therapy (Rebt) Untuk Mengurangi Perilaku Bullying Pada Siswa Abk Di Sekolah Dasar Inklusif. Jurnal Bimbingan Dan Konseling Ar-Rahman, 4(1), 35. https://doi.org/10.31602/jbkr.v4i1.1368.

Putri, D. A., Yendi, F. M., Taufik, T., \& Yuca, V. (2019). Rational Emotive Behavior 
Therapy (REBT) Guidelines To Reduce Student Aggressiveness. SCHOULID: Indonesian Journal of School Counseling, 4(3), 83. https://doi.org/10.23916/08429011.

Sari, B. D. K. R., \& Lianawati, A. (2020). Bimbingan kelompok cinema therapy efektif meningkatkan perilaku prososial pada siswa SMPN 3 Waru. 4(2), 189-196. https://doi.org/10.2653/teraputik.42439.

Schumm, M. F., \& Bogner, F. X. (2016). Measuring adolescent science motivation. International Journal of Science Education, 38(3), 434-449. https://doi.org/10.1080/09500693.2016.1147659.

Sugiyono. (2019). Meode Penelitian Kuantitatif Kualitatif dan R\&D (2nd ed.). Alfabeta.

Sumara, D. S., Humaedi, S., \& Santoso, M. B. (2017). Kenakalan Remaja Dan Penanganannya. Prosiding Penelitian Dan Pengabdian Kepada Masyarakat, 4(2). https://doi.org/10.24198/jppm.v4i2.14393.

Van der Graaff, J., Carlo, G., Crocetti, E., Koot, H. M., \& Branje, S. (2018). Prosocial Behavior in Adolescence: Gender Differences in Development and Links with Empathy. Journal of Youth and Adolescence, 47(5), 1086-1099. https://doi.org/10.1007/s10964-017-0786-1.

Voltan Acar, N., \& Şahin, E. S. (2019). Rational emotive behavior therapy from a new perspective. Journal of Human Sciences, 16(4), 894-906. https://doi.org/10.14687/jhs.v16i4.5821.

Wardani, L. K., \& Sari, D. K. (2018). Analisa Kemampuan Mengontrol Marah ditinjau dari Penerapan REBT (Rational Emotive Behaviour Theraphy) pada Klien Skizofrenia di UPT Bina Laras Kras Kediri. Strada Jurnal Ilmiah Kesehatan, 7(2), 57-61. https://doi.org/10.30994/sjik.v7i2.173.

Widyanti, A., Dharsana, I. K., \& Suarn, N. K. (2019). Efektivitas Konseling Kognitif Sosial Teknik Bermain Peran untuk Meningkatkan Self Afiliasi. Jurnal Ilmiah Bimbingan Konseling Undiksha, 10(1), 32-40. https://doi.org/10.24036/XXXXXXXXXX-X.

Wirga, M., DeBernardi, M., Wirga, A., Wirga, M. L., Banout, M., \& Fuller, O. G. (2020). Maultsby's Rational Behavior Therapy: Background, Description, Practical Applications, and Recent Developments. Journal of Rational-Emotive \& CognitiveBehavior Therapy. https://doi.org/10.1007/s10942-020-00341-8.

Yulianingsih, E., Sujawaty, S., \& Rasyid, P. S. (2020). Pelatihan Ketrampilan Pengembangan Kompetensi Psikososial Pada Remaja Di Smp Negeri 6 Kota Gorontalo. GEMASSIKA: Jurnal Pengabdian Kepada Masyarakat, 4(2), 119-127. https://doi.org/10.30787/gemassika.v4i2.578. 